\title{
Some Lessons Learned For Sustainable Development From The Mexican Experience
}

Patricia T. Papachristou, (Email: ppapachr@pbu.edu), Christian Brothers University Gerald C. Papachristou, University of Memphis

\begin{abstract}
The economic reforms that are necessary to implement the neo-liberal paradigm have to be tempered in developing countries by the crucial roles of the national government in the organization, administration and monitoring of institutions that will carry out these reforms. In addition to these reforms, countries like Mexico, where half the population lives below the poverty line, need a nationally-funded and administered program to uplift the rural and urban poor. Mexico has developed such a program that has significantly improved the health and nutrition of mothers and children and class attendance. On the other hand, federal governments of wealthy nations, who espouse free market operations, can by their actions thwart free trade in order to win elections. We examine how very large agricultural subsidies to American farmers and corporations distort the price of corn and corn products in Mexico in a way that makes it difficult for many small farmers to survive. These subsidies go against the free trade principles of the North American Free Trade Agreement (NAFTA), signed by the United States, Mexico and Canada in 1994, but are justified by loopholes included in the final text. The concept of sustainable development provides a way of looking at development programs from a long-term view, with the welfare of the next generation in mind. While the poverty program, described above, has been shown to improve the nutrition. health and school attendance of many poor children, so they can expect to lead a better life than their parents, the NAFTA free trade treaty has worked to enrich a few multi-national businesses at the expense of the welfare of many farmers throughout Mexico and North America. Having used organic methods of farming that preserved the land's fertility and productivity, Mexican small farmers now have to leave the land for the over-crowded cities with little hope of making a good livelihood for their families.
\end{abstract}

\section{INTRODUCTION}

6 ur neighbor, Mexico, has become more closely interwoven into the United States economy over the past ten years. Without trying to analyze the overall strengths and weaknesses of this important relationship, we examine and analyze Mexico's recent experience, in order to draw a few significant lessons for sustainable development that would be of value to other countries with large poor populations facing similar pressures for social and economic development.

By sustainable development, we mean programs and practices that promote, not only the present, but the future well-being of the vast majority of the population and the natural environment in which they live, so that future generations can also prosper. Mexico is a country of extreme economic and social contrasts in the lifestyle of its people. Many still live in extreme poverty and up to 50 per cent of the population is considered by some analysts to be in the ranks of the poor. Despite improvements in the standards of living and national economic indices, large inequalities exist between the better-off and the have-nots. Writing in 1998, Nora Lustig called this high percentage of poverty and inequality: "the unfinished agenda"(p.99). 
Lesson Number One: A social safety net for the extreme poor can be organized successfully, even in a large country like Mexico.

Building on an earlier program under President Salinas that was discontinued in 1994, the Progresa program was organized by President Zedillo in 1997 to provide money from the federal government to poor families that get regular health check-ups, mothers attend monthly sessions on nutrition and hygiene, and make sure their children attend school consistently. President Fox continued the program under a new name, Opportunidades, after taking over in 2001, as the first democratically elected president in recent times. Because of the success of the Progresa program in reaching 2.5 million people and the effectiveness of its evaluation process, which the World Bank deemed impressive, Fox was able to able to get additional international funding (from the International Development Bank, for instance,) to help extend the program to the urban poor. By the end of 2002 the program was benefiting 21 million Mexicans, $20 \%$ of the population. (World Development Report 2004, 30-1)

Pregnant mothers receive regular nutritional packages that continue after child- birth. If the family fulfills these conditions (and they are carefully monitored), the mother receives monthly cash payments averaging 35 dollars in 2003, adjusted for inflation every six months. Children of poor families who would normally work to help the family survive, instead of attending school, can qualify for an extra bonus per child by attending school $85 \%$ or more of the time. While these payments may not appear adequate, they often amount to 20 per cent of the family income.

The results have been "impressive," in both, the coverage of those in poverty and the gains in health, nutrition and school attendance, according to a recent study by the World Bank. Sixty percent of the payments go to the poorest 20 per cent of the national income distribution and 80 per cent of payments to poorest 40 per cent. Significant increases were achieved in school attendance for both boys and girls. Illnesses fell 25 percent among new born and 20 per cent among children under 5 years. Anemia in children 2-5 years was reduced by 19 per cent and adult health also improved. Better nutrition improved the health of most families (Ibid.).

In summary, the Opportunidades program not only increased the incomes of the poor, but also raised the "future productivity" and future earnings of these children. Mothers are much more likely to have healthy children who survive their fifth birthday and do better in school. Careful records were kept to assure the participation of the members of these families. A professional organization from outside of the country was in charge of the evaluation to prevent political interference and to maintain its credibility. The high quality of the evaluation made the program work from the beginning (Ibid.).

Lesson number two: The task of increasing the income of the poor and the "moderate poor" of small, selfemployed individuals and families has been much more difficult than expected, in the post-NAFTA (North American Free Trade Agreement of 1994) world of "free trade."

Estimates of up to 15 million people have been forced to leave their land since 1994 (Public Citizen, p. 3; Oxfam). This may well have been a result partially of the Ejido land reforms in 1992, which allowed community farms to be bought and sold for the first time to pay farm debts. Soon after, most government supports for the small farmer were gradually withdrawn (Lustig, p.99). In addition, the peso crisis of 1994 caused a major decline in income for most Mexicans. But the 2002 estimate of 600 farmers per day quitting in 2002 (Public Citizen, p. 3) indicates a rural crisis that is some way linked to the collapse of corn prices, the staple grain of most Mexicans and other agricultural products, like wheat, sugar and coffee. Most of those leaving the rural areas become either migrants to the cities, which are already very over-crowded, or to the United States if they can cross the border successfully.

We want to try to address this complicated issue by concentrating on the changing value of the corn harvest in the rural areas. Since most farmers grow corn, a staple of the Mexican diet, the dramatic decrease of 70 per cent in the real price of Mexican corn on the world market often threatens their livelihood. The availability of U.S. corn in regional and local markets of Mexico at prices well below the cost of producing a bushel makes it very difficult for the farmer to sell his surplus for the income he needs to survive. 
But it is not just the Mexican farmer who has difficulty surviving. Both the Canadian and American farmers are hurting, as farm prices keep falling. Canada lost 11 per cent of its family farms in 5 years from 1996-2001 and 24 per cent of its farm income from 1989-2001, while farm debt doubled. In the U.S. 38,000 small farms have gone out of business and farm income is still in decline. Only very generous government subsidies keep many more from losing their land (Public Citizen, p. 4).

The realities of the NAFTA agricultural provisions were a far cry from what most people think of as a free trade agreement. Free markets denote the absence of government involvement in affecting price. How strange for the most developed free market economy in the world to have the government give billions of dollars in agricultural subsidies, mostly going, not to struggling farmers, but to big commercial enterprises.

This, in turn, has led to an overproduction in American markets, with the excess dumped in Mexico and other countries. Since NAFTA was passed, U.S. corn exports to Mexico have tripled and now account for almost one third of the Mexican market. American agricultural subsidies for corn have resulted in destroying the livelihood of many Mexican corn farmers. In the year 2000 American corn producers received $\$ 10.1$ billion in subsidies. The Mexican government and its farmers cannot compete against these huge subsidies that effectively lower the price below production cost. In the Oxfam Briefing Paper, "Dumping Without Borders," the value of these subsidies are estimated in two ways: The first uses a cost of production versus the export price to Mexico. Between 2000 and 2002 Oxfam estimated that corn was exported for $\$ 20$ less than production cost per metric ton. This resulted in an implicit subsidy around $\$ 105$ million. The second method used an implicit subsidy based on an average corn subsidy of $\$ 27$ per metric ton of corn produced during the same time period. The volume of corn exported to Mexico was multiplied by $\$ 27$ to get a subsidy of $\$ 145$ million per year. In addition, there is an export credit that large traders, such as Cargill and Archer Daniels Midland (ADM) get in Mexico as importers of American corn (Oxfam, Dumping...," p. 12). The OECD estimated that this export credit for corn would be worth at least US \$15 million in 2002.

In this way, a few multinational agri-businesses have been able to manipulate the corn trade, the price and availability of corn flour through their milling operations and other corn products. The price of corn may have sharply declined but the price of tortillas in Mexico made from corn flour continues to increase. This reflects the ability of big businesses to control the various corn markets by their vertical and horizontal integration. Eighty per cent of U.S. corn sent abroad is exported by three companies: Cargill, Archer Daniel Midland (ADM) and Zen Noh. Similarly, 50 per cent of chicken processing and production is by four companies and four U.S. beef- packers control 81 per cent of U.S. market. (Public Citizen, p. 2)

Most of the increase in U.S. agricultural imports from Mexico comes from U.S.-owned agribusinesses and produced on large plantations using poorly paid workers in inferior working conditions, often using pesticides banned in the U.S. (Oxfam). While all other farmers are losing income, U.S. agri-businesses are making enormous profits. Cargill's net earnings doubled during the period 1999-2003. ConAgra's net income increased from $\$ 437$ million to $\$ 774$ million in 2003. ADM's net earnings were $\$ 511$ million in 2003 , but it spent $\$ 3.5$ billion on plant acquisition, construction and expansion. It also has a 29 per cent interest in the Mexican company Gruma S.A., considered the world's largest producer and marketer of corn flour and tortillas, with significant operations in Mexico (Public Citizen, "NAFTA..."p. 2). ADM also has a third ownership in Maseca, another large processor of corn flour in Mexico and manufacturer of tortillas in the U.S. and Mexico. Cargill has important ties with other flour processors, such as Minsa.

Lesson number three: Looking at the recent Mexican experience, the NAFTA treaty is not working for the Mexican farmer. What can be done to fix it, so it operates in their interests as well, and to sustain development rather than the opposite?

The concept of the need to preserve food security and food sovereignty for the many small farmers as a major principle of agricultural policy has gradually been lost. In the discussions over the nature of the NAFTA treaty, representatives of large agri-businesses argued that agriculture was just another big industry now, and should be treated that way, giving no special deals to the small farmer. Traditional agricultural trade limits on imports were being used to protect the small farmer and to keep prices high enough so he could make a living. The three member 
governments agreed to remove all such trade limitations, but allowed some government subsidies to continue. Such large subsidies and export credits give American companies an overwhelming advantage in the sale of cotton, rice, sugar and soy beans in the markets of the developing world (Tyson), in much the some way as corn is sold (dumped) below the production cost of the local farmer in Mexico. West African cotton farmers have been complaining they cannot grow cotton at the price of the U.S. product available in their markets. Cotton, like corn, is heavily subsidized by the American taxpayer (On Africa, see Roger Thurow).

What needs to be done? First, the NAFTA and World Trade Organization treaties have to be reformed in order to protect millions of farmers who are presently at risk. The right to food security and food sovereignty should be reaffirmed and made a basis upon which these treaties are rewritten. These were agreed to in the United Nations Charter on Human Rights and signed by all the members. Second, most subsidies for farmers and agricultural trading corporations should be removed. But these steps may take time to organize and to renegotiate. In the meantime, there are some short-term remedies that could help the farmer faced with these destructive international forces.

\section{Short-term Remedies}

Faced with a rigged price system in agricultural products, farmers and governments must find ways to protect themselves from forces that are destroying the small farmer in Canada, the U.S. and Mexico (and in other countries around the world). The following five remedies are recommended:

1. Governments, like Mexico, must reclaim their right to food security and food sovereignty in order to protect their farmers from international predators. We are not referring to free market forces and the effects of free trade, but billions of dollars provided yearly by the U.S. government in subsidies and export credits, most of which goes to a few very large transnational corporations. This aid distorts the free market and threatens the livelihoods of farmers all over the world.

2. Facilitate the organization of farmer cooperatives. Without cooperatives, it is difficult for a farmer to get a good price for his output. Middlemen are able to buy grain at below market prices from a farmer, by claiming his crop is below standard in quality, even if it is not, or by lying about the market price. As a member of a cooperative, your organization can hire knowledgeable graders of quality and good negotiators to get the best price for the collective crop of the members. One successful cooperative in Chiapas in Southern Mexico, representing five thousand small producers, was able to improve on the initial offer of 1,100 pesos per ton of corn from Maseca, the main buyer in the region. They finally agreed to a price of 1,360 pesos. Another promising project, called "Our Corn," started by COPRODESA, a cooperative in Puebla, has organized a network of tortilla shops (Dumping Without Borders, p.21-22). This provides some competition for Maseca, the largest corn flour processor in Mexico. But organizing effective cooperatives will not be enough in the long run. They can be taken over by powerful companies, as happened in Canada with two important agricultural cooperatives (Oxfam, "Dumping...").

3. Re-impose tariffs and trade limits on the importation of corn into Mexico to offset the threat to Mexican agriculture from the U.S. subsidies. This option is allowed under the NAFTA treaty until 2008, but has not been utilized by the Mexican government. Other countries have done this on a temporary basis, including the U.S. with tomatoes and avocados.

4. At the same time, Mexico should join with other victimized developing countries to put diplomatic pressure on the:

a. Governments of the U.S. and the European Union to reduce these subsidies drastically, especially the ones going to large corporate farms and transnational corporations,

b. Developed nations and other large agricultural exporters to participate in the on-going Doha Development Round of discussions with the developing nations to rewrite the agricultural provisions of the World Trade Organization (WTO) and NAFTA treaties so as to protect the 
livelihood of the small farmer in Mexico and around the world (Bhagwati, 2002, 2004; Miller; "Right Now..."). Trade representatives of the European Union and the United States have been promising to do this for more than ten years.

5. Promote sustainable development by encouraging organic farming (agro-ecology). Provide special microloans and technical assistance for farmers so that they can continue to grow their corn successfully without pesticides and commercial fertilizers and special seeds that cannot be reused. Recent studies have shown that organic farming methods can be almost as productive as heavy fertilizer and pesticide use. The cumulative damage to the environment and people's health from these modern methods of farming is well known in scientific circles, but ignored by the mainstream U. S. media (Halweil, p.69). Lester Brown has called attention to the ecological deficits that have been piling up as we, not only pollute our environment, but also routinely clear-cut forests, over-fish, overgraze, and overproduce (Brown, 2001,2003).

There is a growing international market for organically grown produce. Global sales of organic foods climbed to $\$ 23$ billion in 2002. Organic crops with world- wide certification were farmed on 23 million hectares (approximately 57 million acres). Many more crops were raised without agro-chemicals, but were not certified as organic (Halweil, p.78). Although large numbers of indigenous farmers in the poorest southern states of Mexico do not use chemicals in their farming, they are not certified as organic growers and so are ineligible for the higher price of their produce. But by belonging to a local farm cooperative representing indigenous growers, a farmer will not only get a better price for his output, but also help in certifying his crops as organic. (See above)

Mexican farming traditions, generally-speaking, are well suited to organic farming which sustains the fertility of the soil and the cleanliness of the water and air. Over 150 varieties of corn are being grown in one Mexican state, Oaxaca (Guenette, 2000). Farmers have learned over the years to use a different variety of corn for each type of soil and habitat on the farm. One variety might grow best in a rocky area with limited soil, others, in an area that gets less rain or less sun. In this way, they practice naturally techniques that encourage "bio-diversity" (in corn) which scientists believe is an essential element in preserving the planet for the next generations.

\section{CONCLUSION}

Some positive and negative lessons can be learned from the recent Mexican experience in modernizing its economy and society. In this paper we examine a few of these experiences and programs in the context of "sustainable development." By this, we mean the impact of development and change in the long run, change that improves both the living standards and the necessary skills of the many to enable them and their children to prosper in the future. The Progresa/ Opportunidades Program is playing an important role in improving the basic health, education and nutritional standards of a fifth of the population. On the other hand, the new era of NAFTA and, so called, free trade has left many farmers destitute, and others hanging on to their farms with great difficulty, as the price of their corn and other produce keep falling.

It is not free trade when the U.S. government provides $\$ 10$ billion in subsidies to farmers, just for corn. It is not free trade when a few transnational, agri-businesses, besides getting most of these subsidies from their large farms in the U.S., also receive large export credits for exporting U.S. corn into Mexico for their flour mills and to sell (dump) on the market at below production costs. While some short term recommendations are made to help the Mexican farmer, only a rewriting of the agricultural sections of the NAFTA and WTO treaties can make a real difference in correcting the farmers' decreasing ability to prosper from the land.

This analysis illustrates a major disagreement over the proper role of the state. Whereas many neo-liberals prefer a minimum role for the state in protecting property and providing certain public goods, such as education and barebones regulation, other economists, such as Joseph Stiglitz, see the state and the market as partners that complement each other. Mexican presidents over the past 20 years have accepted the "neo-liberal paradigm" that emphasizes the role of such principles as, free markets, rather than their former, protected markets, including the opening up of trade to foreign competition, deregulation and privatization of government-run businesses. But, in a world of a few large, transnational, agricultural corporations, the government has to play an active role in seeing that 
trade and competitive practices are carried out fairly. Trade treaties need to be rewritten to protect large numbers of small farmers in developing nations who are vulnerable to powerful corporate and national economic entities.

\section{REFERENCES}

1. Babb, Sarah. Managing Mexico: Economists from Nationalism to Neoliberalism. New Jersey: Princeton University Press, 2001.

2. Bailey, John. Agricultural Trade and the Livelihoods of Small Farmers, Oxfam Great Britain Discussion Paper, www.oxfam.org.uk, March 2000.

3. Bhagwati, Jadish. Don't Cry for Cancun. Foreign Affairs, Jan-Feb.2004, 52-63.

4. - The poor's best hope. The Economist, June 20, 2002.

5. Brown, Lester R. Eco-Economy: Building an Economy for the Earth. New York: Norton, 2001.

$6 . \quad$ _ Plan B: Rescuing a Planet under Stress and a Civilization in Trouble. New York: Norton, 2003.

7. Burfisher, Mary E., Sherman Robinson, and Karen Thierfelder. The Impact of NAFTA on the US. Journal of Economic Perspectives, Volume 15, No. 1: Winter 2001, 125-44

8. Campbell, Monica. Coming to a store you? Mexico's dust-busting doormat, Christian Science Monitor, January 27, 2005, 7.

9. Cancun challenge. The Economist, Sept.4, 2003. www.economist.com (ID=2035492).

10. Cap it all, The Economist, June 26, 2003.

11. Christy, Ralph D. (ed). Achieving Sustainable Communities in a Global Economy, New Jersey: World Scientific, 2004.

12. Commission of the European Union. CAP reform: Commission introduces simplified agricultural state aid regime, Dec.10, 2003, Brussels, Belgium (DN:1P/03/1691), 1-4.

13. Crandall, Russell. Mexico's Changing Domestic and International Dynamics, in Latin America in a Changing Global Environment, edited by Roett Riordan, Guadalupe Paz, Boulder, Colorado: Lynne Rienner, 2003.

14. Dangerous activities. The Economist, May 9, 2002. www.economist.com (ID=1120348).

15. Deaton, Angus. Health Inequality, and Economic Development, in Journal of Economic Literature, March 2003, Volume XLI, No. 1, 113-58.

16. Doha squabble. The Economist, May 27, 2003. www.ecomist.com (ID=1666610).

17. Duryea, Suzanne and Carmen Pagés. What Human Capital Policies Can and Cannot Do for Productivity and Poverty Reduction in Latin America. in Latin American Democracies in the New Global Economy, edited by Ana Margheritis, Boulder, Colorado: Lynne Rienner, 2003.

18. Dussel Peteus, Enrique. Polarizing Mexico: The Impact of Liberalization Strategy, Boulder, Colorado: Lynne Rienner, 2000.

19. Education in Latin America: cramming them in, The Economist, September 5, 2002.

20. Fischer, Stanley. Globalization and Its Challenges, American Economic Review, May 2003, 1-30.

21. Floundering in a tariff-free landscape. The Economist, Nov.28, 2002. www.economist.com (ID=1471549).

22. Foster, Phillips and Howard D. Leathers. The World Food Problem: Tackling the Causes of under nutrition in the Third World. Boulder, Colorado: Lynne Rienner, 1999.

23. Glewwe, Paul. Schools and Skills in Developing Countries: Education Policies and Socioeconomic Outcomes, in Journal of Economic Literature. June 2002, Volume XL, No. 2, 436-82.

24. Guenette, Louise. Scientists and Farmers Join Forces to Conserve Mexico's Maize Diversity, in Science from the Developing World Feb.3, 2003.

25. Hartigan, Pamela. Seizing opportunities to provide market access to the poor: Lessons from Social Entrepreneurs, Earth Times, August 30, 2002.

26. Looking south, north or both? The Economist, Feb. 7, 2004, 35-7.

27. Lustig, Nora. Life is not easy: Mexico's Quest for Stability and Growth. Journal of Economic Perspectives, Volume 15, No. 1, winter 2001, 85-106.

28. Mexican Marathon. The Economist, Sept.11, 2003. www.economist.com/agenda (ID=2049618).

29. Miller, Scott. WTO Proposes Ending Farm-Export Subsidies, Wall Street Journal, Feb 13, 2003, A10.

30. Oxfam. Dumping Without Borders: How US agricultural polices are destroying the livelihoods of Mexican corn farmers, Oxfam Briefing Paper 50, www.oxfam.org.uk, 2003. 
31. _ Rigged Rules and Double Standards: Trade, Globalization, and the Fight against Poverty, www.oxfam.org.uk,2004.

32. Pardinas, Juan. Fighting Poverty in Mexico: Policy Challenges, in Mexico under Fox, edited by Luis Rubio. 2004, 66-86.

33. Profile of José Ignacio Avalos Hernandez, Schwab Foundation for Social Entrepreneurship, www.schwabfound.org/schwabentrepreneurships.htm?schwabid=859.

34. Public Citizen. Down on the Farm: NAFTA's Seven-Year War on Farmers and Ranchers in the US, Canada and Mexico. Public Citizen's Global Trade Watch, June 26, 2001. www.citizen.org.

35. Right Now: A new era of trade negotiations, Oxfam Exchange, Winter 2004, 3.

36. Roberts, J. Timmons and Nikki Demetria Thanes, Trouble in Paradise: Globalization and Environmental Crises in Latin America. New York: Routledge, 2003.

37. Schott, Jeffrey. Unblocking the benefits of world trade, The Economist, Oct.30, 2003. www.economist.com $(\mathrm{ID}=2173129$ ).

38. Stiglitz, Joseph. The Roaring Nineties. New York: W. W. Norton, 2003.

39. Suits, Daniel B. Agriculture, in The Structure of American Industry, edited by Walter Adams, 1-27.

40. Survey: Mexico. Rich is rich and poor is poor. The Economist, October 26, 2000.

41. Thurow, Lester. Fortune Favors the Bold New York: Harper Collins, 2003.

42. Thurow, Roger and Scott Kilman. Bitter Harvest: As US food aid enriches farmers, poor nations cry foul, Wall Street Journal, Sept.11, 2003, 1.

43. Tyson, Laura D' Andrea. The farm bill is a \$200 billion disaster, Newsweek, June 3, 2002.

44. UNEP (United Nations Environment Program) Regional Office for Latin America and the Caribbean. Sustainable development in Latin America and the Caribbean: Challenges and Opportunities, July 2002.

45. UNCTAD (United Nations Conference on Trade and Development). Back to Basics: Market Access Issues in the Doha Agenda, UNCTAD/DITC/MISC.73/REV.1, Geneva, Switzerland: 2000.

46. USDA Economic Research Service. Analysis of the Farm Bill 2002 trade provisions, www.fas.usda.gov/info/factsheets/fb2002/trade.html, accessed January 2004.

47. Vaughan, Scott. The Greenest Trade Agreement Ever?: Measuring the Environmental Impacts of Agricultural Liberalization, Carnegie Endowment for International Peace. Will these modest proposals provoke mayhem down on the farm? The Economist, July 11, 2002. www.economist.com (ID=1227864).

48. Williams, Mark Eric. Market Reforms in Mexico. New York: Rowman and Littlefield Publishers, Inc., 2001.

49. World Bank. Globalization, Growth, and Poverty. World Bank Policy Research Report. Washington, D. C. World Bank, 2002.

50. $\quad$ World Bank. World Development Report 1997: The State in a Changing World. New York: Oxford University Press, 1997.

51. World Bank. World Development Report 2003: Sustainable Development in a Dynamic World: Transforming Institutions, Growth and Quality of Life. New York: Oxford University Press, 2003.

52. World Bank. World Development Report 2004: Making Services Work for Poor People. New York: Oxford University Press, 2004.

53. World Bank. Summary and Key Messages, in Poverty in Mexico: An Assessment of Conditions, Trends and Government Strategy, 2004, xvii-lx.

54. World Summit on Sustainable Development one year on: implementing our commitments. Communication from the EU Commission to the Council and the European Parliament, Brussels, Belgium, Dec. 23, 2003.

55. Zoellick, Robert. Unleashing the Trade Winds, The Economist, December 5, 2002. 


\section{NOTES}

